\title{
Gold(I) catalysed regio- and stereoselective intermolecular hydroamination of internal alkynes: towards functionalised azoles
}

\author{
Christophe Michon, ${ }^{*} a, b$ Joachim Gilbert, ${ }^{a, b}$ Xavier Trivelli, ${ }^{c}$ Fady Nahra, ${ }^{d}$ Catherine S. J. Cazin, ${ }^{d}$ Francine Agbossou- \\ Niedercorn, ${ }^{a, b}$ and Steven P. Nolan ${ }^{*} d, e$ \\ a. \\ Univ. Lille, CNRS, Centrale Lille, ENSCL, Univ. Artois, UMR 8181 - UCCS - Unité de Catalyse et Chimie du Solide, F-59000 Lille, France \\ E-mail: christophe.michon@univ-lille.fr \\ b. $\quad$ ENSCL, UCCS-CCM-MOCAH UMR 8181, (Chimie-C7) CS 90108, 59652 Villeneuve d'Ascq Cedex, France \\ c. UGSF CNRS, UMR 8576, Univ. Lille, 59655 Villeneuve d'Ascq Cedex France \\ d. Department of Chemistry, Ghent University, Building S3, Krijgslaan 281, 9000 Gent, Belgium \\ E-mail: steven.nolan@ugent.be \\ e. Department of Chemistry, College of Science, King Saud University, P.O. Box 2455, Riyadh 11451, Saudi Arabia
}

Abstract: Gold(I) catalysed regio- and stereoselective intermolecular hydroamination of internal alkynes was developed for the effective synthesis of a series of (Z)-functionalised vinylazoles under solvent free conditions. The catalytic hydrogenation of the resulting enamines leads to substituted saturated azoles in good yields.

Electronic Supplementary Information (ESI) available: Figures S1 and S2, Table S1, synthetic and catalytic details, NMR spectra of all products. See the web.

$N$-functionalised azoles are important molecular scaffolds for pharmaceuticals, bioactive compounds and natural products. They are useful in the treatment of various diseases as they exhibit antifungal (I), ${ }^{1}$ antibacteria (II), ${ }^{2}$ anxiolytic (III), ${ }^{3}$ analgesic (IV), ${ }^{4}$ antidepressant (IV) ${ }^{4}$ and anticancer (V) ${ }^{5}$ activities (Figure 1). If various methodologies including cycloaddition and multicomponent reactions focused on building these heterocycles, ${ }^{6}$ direct functionalisation of azoles has been much less explored. Considering that the hydroamination of alkenes and alkynes is the shortest synthetic route to secondary and tertiary amines, this reaction should be of practical interest for the preparation of azole derivatives. In this context, if the intermolecular hydroamination of alkenes remains a challenge, the inter- and intramolecular hydroamination of terminal alkynes has been broadly studied. ${ }^{7}$ The resulting substituted enamines, imines or functionalised heterocycles are obtained as Markovnikov or antiMarkovnikov products and are useful intermediates in organic synthesis. Although the intermolecular hydroamination of internal alkynes with primary amines has been effectively performed using Group 4-based catalysts, ${ }^{8}$ the use of other nucleophiles such as dialkylamines or heterocycles remains more challenging due to a lack of general synthetic method. Recently, Schaffer et al. have reported on the use of bis(amidate)bis(amido)titanium(IV) to catalyse the selective anti-Markovnikov hydroamination of terminal and internal alkynes with $N$-silylamines to afford $N$-silylenamines. ${ }^{9}$ The latter either led to primary amines, after desilylation, or to various pyridines through reactions with $\alpha, \beta$-unsaturated carbonyls followed by oxidation. ${ }^{9}$ The versatility of rhodium(I) catalyst was also concomitantly highlighted by several contributions. ${ }^{10}$ Dong et al. and Sunoj et al. reported on the hydroamination of internal alkynes via tandem rhodium catalysis to yield branched $N$-allylic amines and more specifically $N$-allyl indolines with high regio- and enantioselectivities. ${ }^{10 a, e}$ In parallel, Breit et al. have developed a rhodium catalyst allowing for the chemo-', regio-, and enantioselective allylation of pyrrazoles and triazoles with internal alkynes. ${ }^{10 \mathrm{~b}, \mathrm{~d}}$ Interestingly, Zhao et al. combined rhodiumcatalysed hydroamination and $\mathrm{C}-\mathrm{H}$ activation in a highly selective [4+2] imine/alkyne annulation to form multi-substituted 3,4dihydroisoquinolines ${ }^{10}$. Regarding Group 11-based catalysts, Zhu et al. $(\mathrm{Ag}(\mathrm{I}))$ and later Kawatsura et al. (Cu(II)) reported the regioselective intermolecular hydroamination of internal alkynes functionalized with electron-withdrawing groups in the presence of various amines. ${ }^{11}$<smiles>[R4]C=C([R])n1nc([R])c([R])n1</smiles>

Figure 1. Azoles found in the pharmaceutical industry 
In parallel, gold-catalysed additions to CC multiple bonded substrates proved to be effective in intramolecular reactions though intermolecular versions have remained more challenging. ${ }^{12}$ Interestingly, Bertrand et al. have developed gold(I) catalysts based on cyclic(alkyl)(amino)carbenes (CAACs) for the intermolecular hydroamination of alkynes with ammonia, hydrazine and amines. ${ }^{13 a, d}$ This methodology was later applied to the one-pot three-component synthesis of 1,2-dihydroquinolines. ${ }^{13 \mathrm{~b}, \mathrm{c}}$ Thereafter, Stradiotto et al. reported $P, N$-ligand based gold(I) catalysts for the stereo- and regioselective hydroamination of internal alkynes using various dialkylamines. ${ }^{14}$ In parallel, triazole-gold(I) complexes developed by Shi et al. proved to be also valuable catalysts for the intermolecular hydroamination of internal alkynes with primary amines, ${ }^{15 a}$ the reaction yields being improved by the use of an acid co-catalyst. Interestingly, this methodology was further extended to the synthesis of several vinyl-substituted triazoles. ${ }^{15 b}$ Some related pyrazoles were later prepared by Chen et al. through a 1,4-conjugate addition to propiolates using gold(I) chloride as a catalyst. ${ }^{16}$ Following our interests in gold(I)-catalysed hydrophenoxylation, hydroalkoxylation and hydrocarboxylation of alkynes ${ }^{17}$ as well as in gold(I)-catalysed hydroamination of alkenes, ${ }^{18}$ we report here gold(I)-catalysed regio- and stereoselective intermolecular hydroamination of internal alkynes for the effective synthesis of a broad range of functionalised vinylazoles under solvent-free conditions. Interestingly, the subsequent catalytic hydrogenation of the resulting ( $Z$ )-enamines leads to the related saturated azoles in good yields.

Initially, diphenylacetylene $\mathbf{2 a}$ and benzotriazole $\mathbf{3 a}$ were selected as model substrates to test the three selected precatalysts, e.g. $[\mathrm{Au}(\mathrm{IPr})(\mathrm{OH})] \mathbf{1 a},{ }^{19 a}[\mathrm{Au}(\mathrm{IPr})]\left[\mathrm{NTf}_{2}\right] \mathbf{1 b}^{19 b}$ and $\left[\{\mathrm{Au}(\mathrm{IPr})\}_{2}(\mu-\mathrm{OH})\right]\left[\mathrm{BF}_{4}\right] \mathbf{1}^{19 \mathrm{c}}$ and establish the best catalytic conditions (Table 1). Reactions were performed with 0.5 mol\% catalyst loading, in closed vials containing 0.22 mmol of alkyne $2 \mathrm{a}$ without any solvent. The mixtures were heated at $100^{\circ} \mathrm{C}$ for 72 hours using a sand bath (method A) or by using microwave heating at $150^{\circ} \mathrm{C}$ for 0.75 hour (method B). At first, none of the catalysts were active when the reaction was performed using method $\mathrm{A}$ (entries 1-3). However, we found the use of a catalytic amount ( $5 \mathrm{~mol} \%$ ) of $\mathrm{NBu}_{4} \mathrm{OTf}$ as an additive allowed the reactions to proceed. Other ammonium salts bearing anions like $\mathrm{BF}_{4}$ or OTos led also to hydroamination product 4aa but yields were lower and some byproducts were formed. The critical effect of $\mathrm{NBu}_{4} \mathrm{OTf}$ (and of the OTf anion) can be explained by its role in the proto-deauration step (see Scheme 2 and the mechanism discussion below). ${ }^{20,21}$ Indeed, the hydroamination product 4 aa was obtained in a $22 \%$ yield while using catalyst 1a (entry 4 ).

Table 1 Development of the catalytic reaction
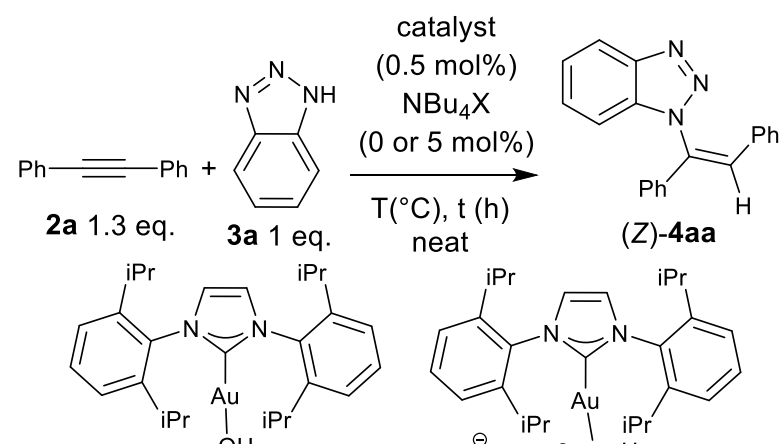

1a $[\mathrm{Au}(\mathrm{IPr})(\mathrm{OH})]{ }^{\mathrm{OH}}$<smiles></smiles><smiles>CC(C)c1cccc(C(C)C)c1N(C)C</smiles>

$\mathrm{iPr}$ $\mathrm{BF}_{4}^{\ominus}{ }^{\mathrm{iPr}} \stackrel{\oplus}{\mathrm{O}}-\mathrm{i}$<smiles></smiles>

1b $[\mathrm{Au}(\mathrm{IPr})]\left[\mathrm{NTf}_{2}\right]$

1c $\left[\{\mathrm{Au}(\mathrm{IPr})\}_{2}(\mu-\mathrm{OH})\right]\left[\mathrm{BF}_{4}\right]$

\begin{tabular}{cccccc}
\hline Entry & $\begin{array}{c}\text { Cat. } \\
(\mathrm{mol} \%\end{array}$ & $\begin{array}{c}\mathrm{NBu}_{4} \mathrm{X} \\
(\mathrm{mol} \%)\end{array}$ & $\begin{array}{c}\mathrm{T}\left({ }^{\circ} \mathrm{C}\right) \\
(\mathrm{method})\end{array}$ & $\begin{array}{c}\text { time } \\
(\mathrm{h})\end{array}$ & $\begin{array}{c}\text { Yield } \\
(\%)^{\mathrm{b}}\end{array}$ \\
\hline 1 & 1a & 0 & $100(\mathrm{~A})$ & 72 & - \\
2 & 1b & 0 & $100(\mathrm{~A})$ & 72 & - \\
3 & 1c & 0 & $100(\mathrm{~A})$ & 72 & - \\
4 & 1a & $\mathrm{X}=$ OTf (5) & $100(\mathrm{~A})$ & 72 & 22 \\
5 & 1b & $\mathrm{X}=$ OTf (5) & $100(\mathrm{~A})$ & 72 & 61 \\
6 & 1c & $\mathrm{X}=$ OTf (5) & $100(\mathrm{~A})$ & 72 & 66 \\
7 & 1c & $\mathrm{X}=$ OTf (5) & $100(\mathrm{~A})$ & 72 & $44^{\mathrm{c}}$ \\
8 & 1c & $\mathrm{X}=$ OTf (5) & $150(\mathrm{~B})$ & 0.75 & 66 \\
9 & 1c & $\mathrm{X}=$ OTf (5) & $150(\mathrm{~B})$ & 0.75 & $96^{\mathrm{c}}$ \\
\hline
\end{tabular}

a) Method A using a sand bath at $100^{\circ} \mathrm{C}$ for $72 \mathrm{~h}$, method $B$ using microwave heating at $150^{\circ} \mathrm{C}$ for $0.75 \mathrm{~h}$.

b) $0.22 \mathrm{mmol}$ of $3 a$ used, isolated yields. c) $1.10 \mathrm{mmol}$ of $3 a$ used, isolated yields. 
<smiles>c1ccc2[nH]nnc2c1</smiles>

$3 a$<smiles></smiles>

3b

$3 c^{a}$<smiles>CN1CCNC1=O</smiles><smiles>c1cn[nH]c1</smiles>

$3 e$<smiles>c1ccc2[nH]ncc2c1</smiles><smiles>c1nc[nH]n1</smiles><smiles>c1c[nH]cn1</smiles>

$3 f$

$3 \mathbf{g}$

$3 h$

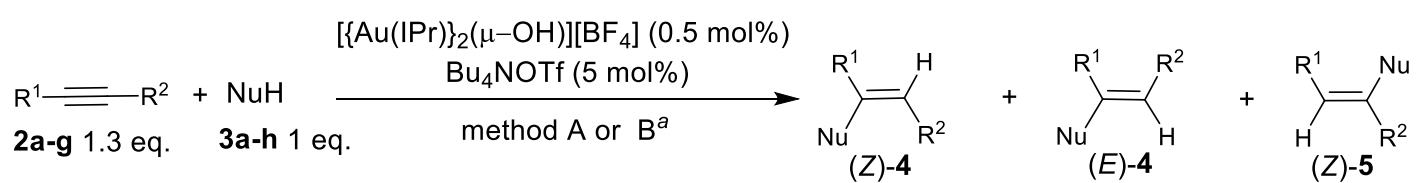<smiles>C(#Cc1ccccc1)c1ccccc1</smiles>

(Z)-4aa
A: $66 \%, B: 96 \%$<smiles>C(=C(c1ccccc1)n1nccn1)c1ccccc1</smiles>

(Z)-4ab

(Z)-4ac

A: $31 \%, B: 57 \%$ A: $15 \%, B: 21 \%$
$\left[C_{\mathrm{Ph}}^{\mathrm{Ph}}=\mathrm{O}\right.$

(Z)-4ad (E)-4ad

Ratio (Z)-4ad / (E)-4ad (68/32)

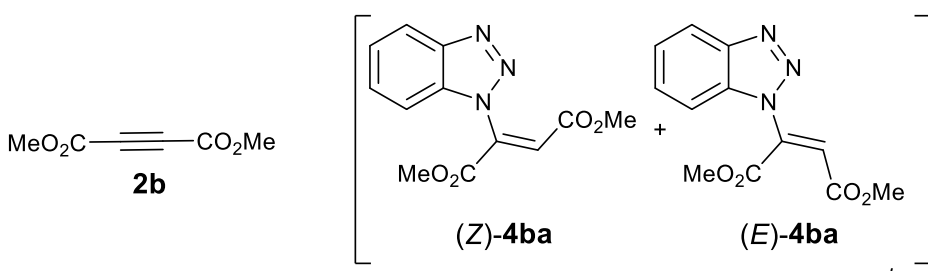

A: $69 \%,{ }^{C}$ Ratio $(Z)-4$ ba / (E)-4ba $(1 / 1)^{b}$<smiles>COC(=O)/C(=C/[14C](=O)OC)n1cccn1</smiles>

A: $56 \%$, B: $65 \%$, Ratio (Z)-4be / (E)-4be $(1 / 9)^{b}$

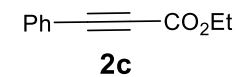

2c<smiles>CCOC(=O)/C=C(\c1ccccc1)n1nnc2ccccc21</smiles>

$(Z)-4 \mathbf{c a}$<smiles>CCOC(=O)/C=C(\c1ccccc1)n1ccnn1</smiles>

(Z)-4cb<smiles>CCOC(=O)/C=C(/c1ccccc1)n1cccn1</smiles>

(Z)-4ce<smiles>CCOC(=O)/C=C(\c1ccccc1)n1ncc2ccccc21</smiles>

(Z)-4cf

A: $88 \%$, B: $50 \% \quad$ A: $70 \%, B: 70 \%$

A: $65 \%$<smiles>N#CC#Cc1ccccc1</smiles>

(Z)-4de

A: $91 \%$, B: $67 \%$

A: $10 \%, B: 14 \%$

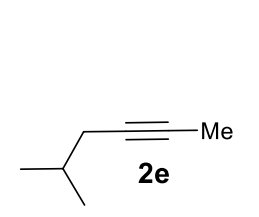

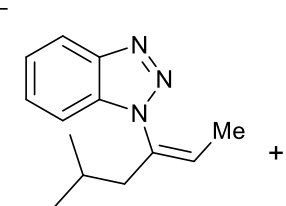

(Z)-4ea

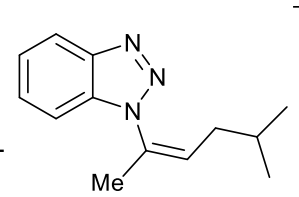

(Z)-5ea

A: $75 \%$, Ratio 4ea / 5ea $(23 / 77)$<smiles>C/C=C(/c1ccccc1)n1nnc2ccccc21</smiles>

Ratio 4fa / 5fa: $(3 / 7)^{b}$<smiles>CC(C)C#CC(C)C</smiles>

(Z)-4ga

$\mathrm{NuH} \mathrm{pKa}^{d} 11.9$

A: $70 \%$, B: $80 \%$<smiles>CC/C(=C/C(C)C)n1ccnn1</smiles>

(Z)-4gb
(Z)-4gc

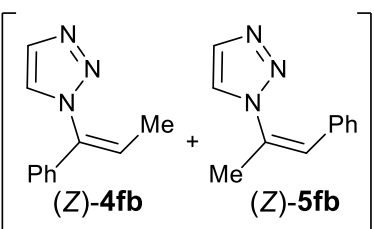

A: $76 \%$,

Ratio 4fb / 5fb: $(23 / 77)^{b}$<smiles>CC(C)/C=C(/C(C)C)n1nccn1</smiles><smiles>CC(C)/C=C(/C(C)C)n1cccn1</smiles>

(Z)-4ge

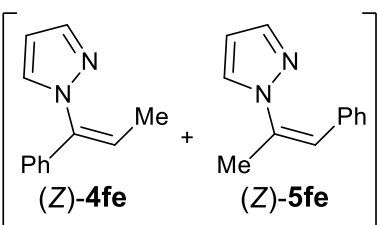

A: $83 \%$,

Ratio 4fe / $5 \mathrm{fe}(2 / 8)^{b}$
Scheme 1 Scope of the reaction. ${ }^{a}$ Method A using a sand bath at $100^{\circ} \mathrm{C}$ for $72 \mathrm{~h}$, method $B$ using microwave heating at $150^{\circ} \mathrm{C}$ for 45 min., isolated yields; ${ }^{b}$ determined by ${ }^{1} \mathrm{H}$ NMR; ${ }^{c} 6 \mathrm{~h}$ reaction; ${ }^{d}$ pKa in reference to DMSO 
A change to catalysts $\mathbf{1 b}$ and $\mathbf{1 c}$ led to a significant increase in yields of $\mathbf{4 a a}$ to $61 \%$ and $66 \%$, respectively (entries 5 and 6 ). Finally, the reaction was performed on a larger scale starting with $1.1 \mathrm{mmol}$ of $\mathbf{2 a}$. While a decrease in product 4aa yield was noticed using a sand bath for 72 hours (method A) (entry 7), we observed a nearly quantitative yield, e.g. 96\%, of enamine 4aa by employing microwave heating for 0.75 hour (method B) (entry 9). It is noteworthy that similar yields of 4 aa were obtained starting from 0.22 mmol of $\mathbf{2 a}$ and applying method $\mathrm{A}$ or $\mathrm{B}$ (entries 6,8$)$.

The scope of the gold(I)-catalysed hydroamination was studied for a series of alkynes and azole nucleophiles by using method $A$ and $B$ (Scheme 1 and Figure 2). The $(Z) /(E)$ (cis/trans) isomerism of pure or mixed isomers was established based on the observed and non-observed NOEs profiles after full assignment of ${ }^{1} \mathrm{H} /{ }^{13} \mathrm{C} /{ }^{15} \mathrm{~N}$ chemical shifts (see the SI for details). By studying all hydroamination products 4 , we noticed the ${ }^{3} J\left({ }^{1} \mathrm{H}-{ }^{15} \mathrm{~N}\right)$ coupling constants were larger than or equal to $4.8 \mathrm{~Hz}$ for all $(Z)$-enamines and less than $2 \mathrm{~Hz}$ for the $(E)$-enamines in agreement with previous analyses ${ }^{23}$ (see SI, Figures S1,S2). At first, diphenylacetylene $\mathbf{2} \mathbf{a}$ was reacted with benzotriazole $\mathbf{3 a}$ and triazoles $\mathbf{3 b}$-c to lead to the corresponding (Z)-products $\mathbf{4 a a}$, $\mathbf{4 a b}$ and $\mathbf{4 a c}$ in good yields. The reaction with triazole $\mathbf{3} \mathbf{b}$ afforded preferentially the $N^{1}$ addition product $\mathbf{4 a b}$, the $N^{2}$ tautomer product 4 ac being minor. In spite of a high yield, the hydroamination of alkyne $\mathbf{2 a}$ with 1-methylimidazolidin-2-one $\mathbf{3 d}$ was not entirely $(Z)$-selective, a $(Z) /(E)$ ratio of 68/32 was observed for 4 ad. As noticed during the development of the catalytic reaction, the use of microwave heating (method B) led to higher yields for products $\mathbf{4 a a}, \mathbf{4} \mathbf{a b}$ and $\mathbf{4 a c}$. The hydroamination of dimethyl acetylenedicarboxylate (DMAD) $\mathbf{2 b}$ with benzotriazole $\mathbf{3 a}$ afforded a $1 / 1$ mixture of $(Z)$ and $(E) \mathbf{4 b a}$ isomers in a good yield. By comparison, the use of pyrazole $\mathbf{3 e}$ led to a more selective reaction with a mixture of $(Z) /(E)$ 4be isomers in a 1/9 ratio. Unsymmetrical phenylpropiolate 2c underwent hydroamination with azoles $\mathbf{3 a - b}$ and $\mathbf{3 e - f}$ with complete regio- and stereoselectivity and good isolated yields. In contrast, the hydroamination of 3-phenylpropiolonitrile $\mathbf{2 d}$ with pyrazole $\mathbf{3 e}$ led to isolated (Z)-regioisomers $\mathbf{4 d e}$ and $\mathbf{5 d e}$ in a $9 / 1$ ratio and high yields. The reactions of unsymmetrical 5-methylhex-2-yne $\mathbf{2 e}$ and phenylpropyne $\mathbf{2} \mathbf{f}$ with azoles $\mathbf{3 a} \mathbf{b} \mathbf{b}$ and $\mathbf{3 e}$ gave mixtures of the corresponding (Z)-regioisomers 4 and 5 in high yields with ratios from $3 / 7$ to $2 / 8$. The hydroaminations of 4 -octyne $\mathbf{2 g}$ with azoles $\mathbf{3 a}-\mathbf{c}, \mathbf{3 e}$ and $\mathbf{3 g}-\mathbf{h}$ afforded the related enamines $\mathbf{4}$ with complete $(Z)$-stereoselectivity in average to good yields independently of the pKa of the azole nucleophile. It is worth noting that the reaction of 4 -octyne $\mathbf{2 g}$ with triazole $\mathbf{3 b}$ led to a mixture of the preferred $N^{1}$ addition product $\mathbf{4 g b}$ and the minor $N^{2}$ tautomer product $\mathbf{4 g c}$. By comparison to the previous work of Shi et al. who reported the synthesis of several vinyl-substituted triazoles from terminal and internal alkynes using $\mathrm{PPh}_{3} \mathrm{AuOTf}$ catalyst in toluene, ${ }^{15 b}$ our synthetic methodology operates in solvent free conditions and therefore allows practical, simple, and scalable reactions using standard thermal heating or more convenient microwave heating. Moreover, the scope of our reactions is broader and allows the hydroamination of seven internal alkynes with eight heterocycles including triazoles, pyrazoles, imidazole and a cyclic urea to form (Z)-enamines with very minor exceptions.

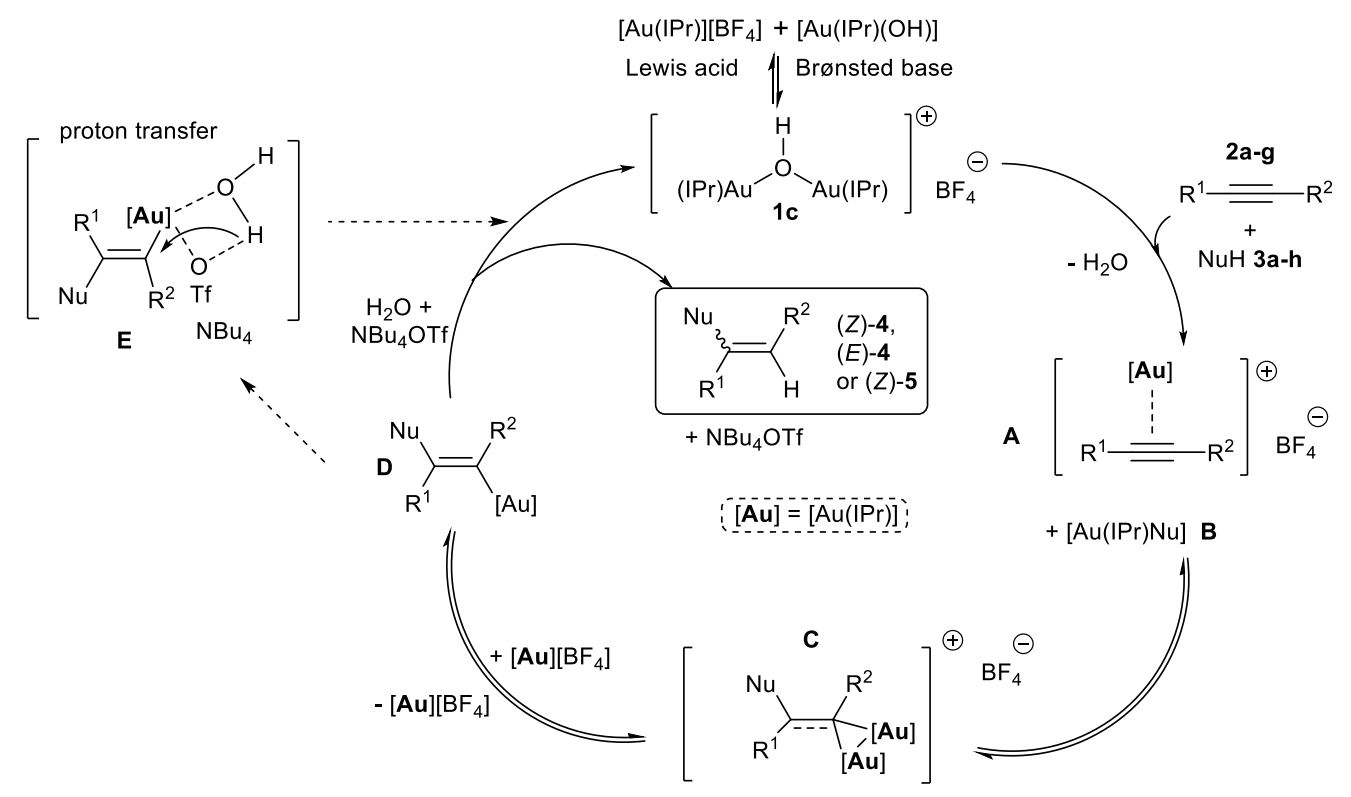

Scheme 2 Proposed reaction mechanism 
Finally, along our study, we observed triazole $\mathbf{3 b}$ reacted preferentially to form the $N^{1}$ addition product, the $N^{2}$ tautomer product being minor or not formed.

Regarding the reaction mechanism, some of us have demonstrated that $\left[\{\mathrm{Au}(\operatorname{IPr})\}_{2}(\mu-\mathrm{OH})\right]\left[\mathrm{BF} \mathrm{F}_{4}\right] \mathbf{1 c}$ is a highly efficient bifunctional catalyst for the hydrophenoxylation, hydroalkoxylation and hydrocarboxylation of internal alkynes. ${ }^{17}$ This complex can be regarded as a catalyst able to activate substrates in a dual-mode providing Lewis acid $[\mathrm{Au}(\mathrm{IPr})]\left[\mathrm{BF}_{4}\right]$ and $\mathrm{Br} \varnothing$ nsted base $[\mathrm{Au}(\mathrm{IPr})(\mathrm{OH})](\mathrm{Scheme} 2)$. On the basis of previous mechanistic studies, ${ }^{17}$ we propose the Lewis acid [Au(IPr)][BF $\left.\mathrm{BF}_{4}\right]$ would coordinate to the alkyne to form species $A^{24}$ and the $B r \varnothing n s t e d$ base $[\mathrm{Au}(\mathrm{IPr})(\mathrm{OH})]$ would deprotonate the azole nucleophile to generate the corresponding gold-azole complex $\mathbf{B}$ and release a water molecule (Scheme 2). Afterwards, the subsequent nucleophilic attack of gold-azole $\mathbf{B}^{15 a}$ toward $\pi$ complex $\mathbf{A}$ in an anti-fashion would lead to the formation of gem-diaurated species $\mathbf{C}^{25}$ or $\sigma$-monoaurated species D $^{26}$ (most likely in equilibrium), C acting as an off-cycle species. Finally, protodeauration with $\mathrm{H}_{2} \mathrm{O}$ and the assistance of OTf anion ${ }^{20,21}$ through intermediate $\mathbf{E}$ would deliver the vinylazole product $\mathbf{4}$ or $\mathbf{5}$ and catalyst $\mathbf{1 c}$. This assisted proton-transfer/protodeauration step underlines the prominent role of counterions during gold catalysed reactions. ${ }^{20,21}$

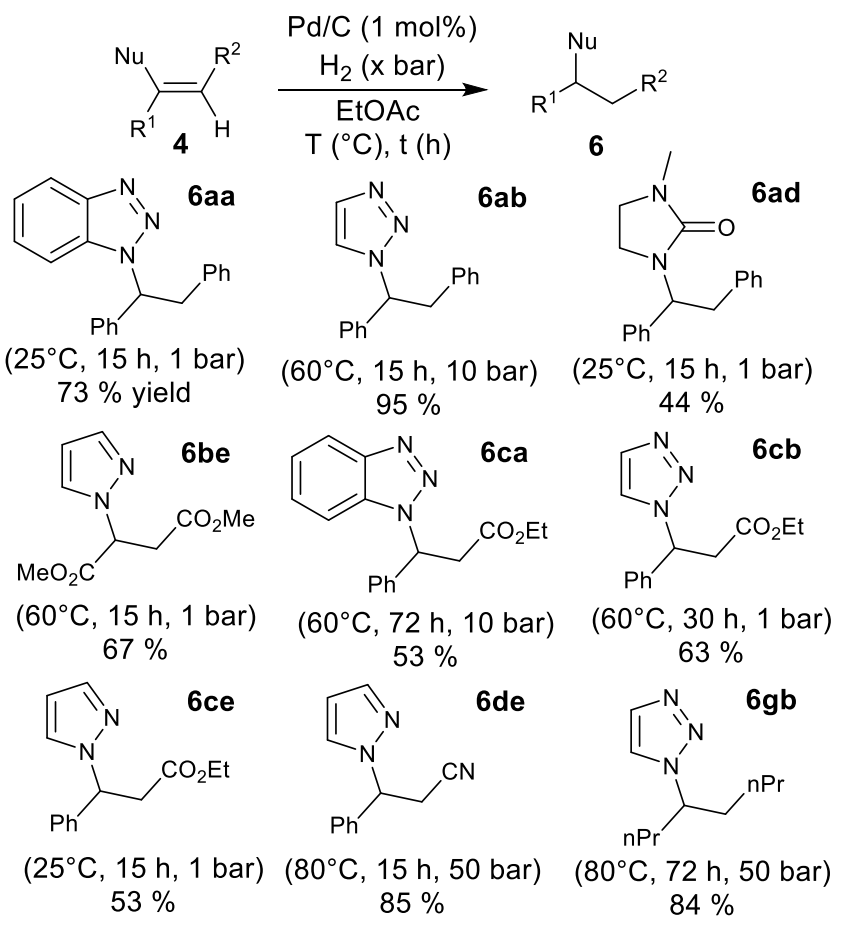

Scheme 3 Hydrogenation of enamines 4

The catalytic hydrogenation of a series of vinylazoles 4 into saturated azoles 6 was then investigated (Scheme 3 and SI, Table S1). Although the hydrogenation of enamines has been well-studied, $8 b, n, 16,27,28$ it is also clear that it suffers from important limitations regarding the reaction activities and selectivities as well as narrow substrate scopes. ${ }^{8 n, 28} \mathrm{~A}$ rapid screening of the reaction conditions determined EtOAc to be the best solvent in order to reach high isolated yields (Scheme 3 and SI, Table S1). The Pd/C catalyst (5\% Pd) loading was set at 1 mol\% and other parameters, e.g. temperature, time and pressure, needed to be adjusted as a function of the substrate. Hydrogenation of enamines 4aa, 4ad and 4ce proceeded smoothly within 15 hours at room temperature and 1 bar of $\mathrm{H}_{2}$. Under the same reaction conditions except heating at $60^{\circ} \mathrm{C}$, triazole and pyrazole derivatives $\mathbf{4 b e}$ and $\mathbf{4 c b}$ were reduced effectively in 15 and 30 hours, respectively. The hydrogenation of enamines $\mathbf{4 a b}$ and $\mathbf{4 c a}$ required 10 bar pressure of $\mathrm{H}_{2}$ and $60^{\circ} \mathrm{C}$ heating to proceed in 15 and 72 hours. As previously observed by Pfaltz et al. and Hou et al. on other similar derivatives, ${ }^{29}$ the hydrogenation of conjugated nitrile 4de into saturated pyrazole 6 de required stronger reaction conditions, i.e. $80^{\circ} \mathrm{C}$ and 50 bar of $\mathrm{H}_{2}$, to reach a very good $85 \%$ yield. The vinyltriazole $4 \mathrm{gb}$ was hydrogenated in a similar manner but required a longer reaction time, 72 hours.

To summarise, we have developed a gold(I)-catalysed intermolecular hydroamination of internal alkynes for the effective synthesis of a broad range of functionalised vinylazoles with fair to high yields and high regio-, chemo-, and stereoselectivity. The use of solvent-free conditions allows a practical, simple, and scalable synthetic methodology using standard thermal heating or more convenient microwave heating. In addition, the catalytic hydrogenation of the resulting ( $Z$ )-enamines led to various substituted saturated azoles in good yields without the 
formation of significant by-products. The present process represents a practical and atom-economical alternative to existing synthetic methods to assemble a variety of functionalised azoles.

\section{Conflicts of interest}

There are no conflicts to declare

\section{Acknowledgements}

The CNRS, the Chevreul Institute (FR 2638), the Ministère de l'Enseignement Supérieur et de la Recherche et de l'innovation, the Région Hauts-de-France and the FEDER are acknowledged for supporting and funding partially this work. The University of Lille is acknowledged for funding partially this work (AO 2016-2017 Lille-Gent-Louvain, G11Flow project). The Bruker 300 AVANCE III spectrometer is co-funded by the European Union with the European Regional Development Fund (ERDF), by the Hauts de France Regional Council (contract $n^{\circ} 17003781$ ), Métropole Européenne de Lille (contract $n^{\circ} 2016 \_E S R \_05$ ), French State (contract $\left.n^{\circ} 2017-R 3-C T R L-P h a s e ~ 1\right)$, the Pasteur Institute of Lille, the Lille University and the French CNRS. Umicore AG is thanked for generous donations of auric acid. Dr M. Kouach (Univ. Lille) is thanked for HRMS analyses. Mrs C. Delabre (UCCS) is thanked for GC-MS and elemental analyses. For work carried out in Ghent, S.P.N. thanks KSU (Distinguished Scientist Program) and VLAIO (Co2perate) for support.

\section{Notes and references}

1 a) M. Ogata, H. Matsumoto, S. Shimizu, S. Kida, M. Shiro and K. Tawara J. Med. Chem., 1987, 30, 1348; b) Z. Rezaei, S. Khabnadideh, K. Pakshir, Z. Hossaini, F. Amiri and E. Assadpour, Eur. J. Med. Chem., 2009, 44, 3064; c) R. Kharb, P. C. Sharma and M. S. Yar, J. Enzyme Inhib. Med. Chem., 2011, 26, 1.

2 M. Cano, A. Palomer and A. Guglietta, (Ferrer Internacional, S. A.) WO 2010000704 (A1), 2010.

3 M. H. Paluchowska, R. Bugno, S. Charakchieva-Minol, A. J. Bojarski, E. Tatarczyńska and E. Chojnacka-Wójcik, Arch. Pharm., 2006, 339, 498.

4 C. E. Park, K. H. Min, Y.-J. Shin, H.-J. Yoon, W. Kim, E.-J. Ryu, C.-M. Chung and H.-K. Kim, (SK Biopharmaceuticals Co. Ltd.) US 20100311789 (A1), 2010.

5 a) J. Zhou, P. Liu, Q. Lin, B. W. Metcalf, D. Meloni, Y. Pan, M. Xia, M. Li, T.-Y. Yue, J. D. Rodgers and H. Wang, (Incyte Corporation, USA) PCT Int. Appl., WO 2010083283 A2, 2010; b) R. Morphy, J. Med. Chem., 2010, 53, 1413.

6 a) A. R. Katritzky and S. Rachwal, Chem. Rev., 2010, 110, 1564; b) R. Sakhuja, S. S. Panda and K. Bajaj, Curr. Org. Chem., 2012, 16, 789; c) S. Mignani, Y. Zhou, T. Lecourt and L. Micouin, Topics in Heterocyclic Chem., 2012, 28, 185; c) P. S. Reddy and A. K. D. Bhavani, Adv. Heterocyclic Chem., 2015, 114, 271; d) P. Singh and K. N. Singh, Org. Biomol. Chem., 2018, 16, 9084.

7 a) S. Doye in Science of Synthesis, Vol. 40a (Eds.: D. Enders, E. Schaumann), Thieme, Stuttgart, 2009, pp. 241; b) L. L. Schafer, C.-H. Jacky and N. Yonson, Transition-Metal-Catalyzed Hydroamination Reactions, in Metal-Catalyzed Cross-Coupling Reactions and More. Wiley-VCH: Weinheim, 2014; c) R. Severin and S. Doye, Chem. Soc. Rev., 2007, 36, 1407; d) T. E. Mueller, K. C. Hultzsch, M. Yus, F. Foubelo and M. Tada, Chem. Rev., 2008, 108, 3795; e) N. T. Patil and V. Singh, J. Organomet. Chem., 2011, 696, 419; f) N. T. Patil, R. D. Kavthe and V. S. Shinde, Tetrahedron, 2012, 68, 8079; g) L. Huang, M. Arndt, K. Gooßen, H. Heydt and L. J. Gooßen, Chem. Rev., 2015, 115, 2596; h) A. M. Haydl, B. Breit, T. Liang and M. J. Krische, Angew. Chem. Int. Ed., 2017, 56, 11312.

8 a) P. J. Walsh, A. M. Baranger and R. G. Bergman, J. Am. Chem. Soc., 1992, 114, 1708; b) E. Haak, H. Siebeneicher and S. Doye, Org. Lett., 2000, 2, 1935; c) A. Tillack, I. Garcia Castro, C. G. Hartung and M. Beller, Angew. Chem. Int. Ed., 2002, 41, 2541; d) L. Ackermann, Organometallics, 2003, 22, 4367; e) A. Heutling, F. Pohlki and S. Doye, Chem. Eur. J., 2004, 10, 3059; f) Z. Zhang, D. C. Leitch, M. Lu, B. O. Patrick and L. L. Schafer, Chem. Eur. J., 2007, 13, 2012; g) D. C. Leitch, P. R. Payne, C. R. Dunbar and L. L. Schafer, J. Am. Chem. Soc., 2009, 131, 18246; h) D. C. Leitch, C. S. Turner and L. L. Schafer, Angew. Chem. Int. Ed., 2010, 49, 6382; i) K. Born and S. Doye, Eur. J. Org. Chem., 2012, 2012, 764; j) I. A. Tonks, J. C. Meier and J. E. Bercaw, Organometallics, 2013, 32, 3451; k) J. C.-H. Yim, J. A. Bexrud, R. O. Ayinla, D. C. Leitch and L. L. Schafer, J. Org. Chem., 2014, 79, 2015; I) Q. Sun, Y. Wang, D. Yuan, Y. Yao and Q. Shen, Dalton Trans., 2015, 44, 20352; m) Y. Y. Lau, H. Zhai and L. L. Schafer, J. Org. Chem., 2016, 81, 8696; n) E. K. J. Lui and L. L. Schafer, Adv. Synth. Catal., 2016, 358, 713.

9 a) E. K. J. Lui, D. Hergesell, and L. L. Schafer, Org. Lett., 2018, 20, 6663; b) E. K. J. Lui, J. W. Brandt and L. L. Schafer, J. Am. Chem. Soc., 2018, 140, 4973.

10 a) Q.-A. Chen, Z. Chen and V. M. Dong, J. Am. Chem. Soc., 2015, 137, 8392; b) A. M. Haydl, L. J. Hilpert and B. Breit, Chem. Eur. J., 2016, 22, 6547; c) R. S. Manan and P. Zhao, Nature Commun., 2016, 7, 11506; d) D. Berthold and B. Breit, Org. Lett., 2018, 20, 598; e) C. Athira, A. Changotra and R. R. Sunoj, J. Org. Chem., 2018, 83, 2627.

11 a) X. Zhang, B. Yang, G. Li, X. Shu, D. C. Mungra and J. Zhu, Synlett, 2012, 23, 622; b) T. Ishikawa, T. Sonehara, M. Minakawa and M. Kawatsura, Org. Lett., 2016, 18, 1422.

12 About gold catalysis with CC multiple bond substrates: a) M. Rudolph and A. S. K. Hashmi, Chem. Commun., 2011, 47, 6536; b) N. T. Patil and V. Singh, J. Organomet. Chem., 2011, 696, 419; c) R. A. Widenhoefer, Chem. Eur. J., 2008, 14, 5382; d) D. J. Gorin, B. D. Sherry and F. D. Toste, Chem. Rev., 2008, 108, 3351; e) A. S. K. Hashmi, Chem. Rev., 2007, 107, 3180; f) D. Garayalde and C. Nevado, ACS Catal., 2012, 2, 1462; g) M. Chiarucci and M. Bandini, Beilstein 
J. Org. Chem., 2013, 9, 2586; h) M. E. Muratore, A. Homs, C. Obradors and A. M. Echavarren, Chem. Asian J., 2014, 9, 3066; i) W. Debrouwer, T. S. A. Heugebaert, B. I. Roman and C. V. Stevens, Adv. Synth. Catal., 2015, 357, 2975; j) A. C. Jones, Top. Curr. Chem., 2014, 357, 133; k) R. Dorel and A. M. Echavarren, J. Org. Chem., 2015, 80, 7321; I) R. Dorel and A. M. Echavarren, Chem. Rev., 2015, 115, 9028; m) J. A. Goodwin and A. Aponick, Chem. Commun., 2015, 51, 8730; n) A. M. Asiri and A. S. K. Hashmi, Chem. Soc. Rev., 2016, 45, 4471; o) D. P. Day and P. W. H. Chan, Adv. Synth. Catal., 2016, 358, 1368; p) D. B. Huple, S. Ghorpade and R. S. Liu, Adv. Synth. Catal., 2016, 358, 1348; q) S. Nayak, B. Prabagar and A. K. Sahoo, Org. Biomol. Chem., 2016, 14, 803; r) N. L. Rotta-Loria, A. J. Chisholm, P. M. MacQueen, R. McDonald, M. J. Ferguson and M. Stradiotto, Organometallics, 2017, 36, 2470; s) L. D'Amore, G. Ciancaleoni, L. Belpassi, F. Tarantelli, D. Zuccaccia, and P. Belanzoni, Organometallics, 2017, 36, 2364; t) D. Liu, Q. Nie, R. Zhang and M. Cai, Adv. Synth. Catal., 2018, 360, 3940; u) D. P. Zimin, D. V. Dar'in, V. A. Rassadin and V. Y. Kukushkin, Org. Lett., 2018, 20, 4880; v) S. Cacchi, G. Fabrizi, A. Fochetti, F. Ghirga, A. Goggiamani and A. lazzetti, Org. Biomol. Chem., 2019, 17, 527.

13 a) V. Lavallo, G. D. Frey, B. Donnadieu, M. Soleilhavoup and G. Bertrand, Angew. Chem. Int. Ed., 2008, 47, 5224; b) X. Zeng, G. D. Frey, S. Kousar and G. Bertrand, Chem. Eur. J., 2009, 15, 3056; c) X. Zeng, G. D. Frey, R. Kinjo, B. Donnadieu and G. Bertrand, J. Am. Chem. Soc., 2009, 131, 8690; d) R. Kinjo, B. Donnadieu and G. Bertrand, Angew. Chem. Int. Ed., 2011, 50, 5560.

14 a) K. D. Hesp and M. Stradiotto, J. Am. Chem. Soc., 2010, 132, 18026; b) N. L. Rotta-Loria, A. J. Chisholm, P. M. MacQueen, R. McDonald, M. J. Ferguson, and M. Stradiotto, Organometallics, 2017, 36, 2470.

15 a) H. Duan, S. Sengupta, J. L. Petersen, N. G. Akhmedov and X. Shi, J. Am. Chem. Soc., 2009, 131, 12100; b) H. Duan, W. Yan, S. Sengupta and X. Shi, Bioorg. Med. Chem. Lett., 2009, 19, 3899.

16 G. Luo and L. Chen, Tetrahedron Lett., 2015, 56, 6276.

17 a) Y. Oonishi, A. Gómez-Suárez, A. R. Martin and S. P. Nolan, Angew. Chem. Int. Ed., 2013, 52, 9767; b) R. M. P. Veenboer, S. Dupuy and S. P. Nolan, ACS Catal., 2015, 5, 1330; c) S. Dupuy, D. Gasperini and S. P. Nolan, ACS Catal., 2015, 5, 6918-6921; d) D. Gasperini, L. Maggi, S. Dupuy, R. M. P. Veenboer, D. B. Cordes, A. M. Z. Slawin and S. P. Nolan, Adv. Synth. Catal., 2016, 358, 3857.

18 a) F. Medina, C. Michon and F. Agbossou-Niedercorn, Eur. J. Org. Chem., 2012, 6218; b) C. Michon, F. Medina, M.A. Abadie, F. Agbossou-Niedercorn, Organometallics, 2013, 32, 5589; c) C. Michon, M.-A. Abadie, F. Medina and F. Agbossou-Niedercorn, Catalysis Today, 2014, 235, 2; d) M.-A. Abadie, F. Medina, F. Agbossou-Niedercorn and C. Michon, Chimica OGGI - Chemistry Today, 2014, 32, 19; e) M.-A. Abadie, X. Trivelli, F. Medina, F. Capet, P. Roussel, F. Agbossou-Niedercorn and C. Michon, ChemCatChem, 2014, 6, 2235; f) M.-A. Abadie, X. Trivelli, F. Medina, N. Duhal, M. Kouach, B. Linden, M. Vandewalle, F. Capet, P. Roussel, I. Del Rosal, L. Maron, F. Agbossou-Niedercorn and C. Michon, Chem. Eur. J., 2017, 23, 10777-10788.

19 For synthetic access to catalysts 1a-c, see: a) 1a: S. Gaillard, A. M. Z. Slawin, S. P. Nolan, Chem. Commun., 2010, 46, 2742; b) 1b: R. M. P. Veenboer, D. Gasperini, D. B. Cordes, A. M. Z. Slawin, C. S. J. Cazin, S. P. Nolan, Organometallics, 2017, 36, 3645; c) 1c: R. S. Ramon, S. Gaillard, A. Poater, L. Cavallo, A. M. Z. Slawin, S. P. Nolan, Chem. Eur J., 2011, 17,1238

20 a) J. B. F. N. Engberts and B. Zwanenburg, Tetrahedron, 1968, 24, 1737; b) J. M. Hanckel and M. Y. Darensbourg, J. Am. Chem. Soc., 1983, 105, 6979; c) L. N. Appelhans, D. Zuccaccia, A. Kovacevic, A. R. Chianese, J. R. Miecznikowski, A. Macchioni, E. Clot, O. Eisenstein and R. H. Crabtree, J. Am. Chem. Soc., 2005, 127, 16299; d) D. L. Davies, S. M. A. Donald and S. A. Macgregor, J. Am. Chem. Soc., 2005, 127, 13754; e) D. García-Cuadrado, A. A. C. Braga, F. Maseras and A. M. Echavarren, J. Am. Chem. Soc., 2006, 128, 1066; f) M. G. Basallote, M. Besora, J. Duran, M. J. FernándezTrujillo, A. Lledós, M. A. Máñez and F. Maseras, J. Am. Chem. Soc., 2004, 126, 2320; g) M. G. Basallote, M. Besora, C. E. Castillo, M. J. Fernández-Trujillo, A. Lledós, F. Maseras and M. A. Máñez, J. Am. Chem. Soc., 2007, 129, 6608; h) G. Kovács, G. Ujaque and A. Lledós, J. Am. Chem. Soc., 2008, 130, 853; i) R. L. LaLonde, W. E. Brenzovich, D. Benitez, E. Tkatchouk, K. Kelley W. A. Goddard III and F. D. Toste, Chem. Sci., 2010, 1, 226; j) H. Mishra, S. Enami, R. J. Nielsen, M. R. Hoffmann, W. A. Goddard III and A. J. Colussi, PNAS, 2012, 109, 10228; k) D. Munz, M. Webster-Gardiner, R. Fu, T. Strassner, W. A. Goddard III and T. B. Gunnoe, ACS Catal., 2015, 5, 769.

21 a) M. Gatto, P. Belanzoni, L. Belpassi, L. Biasiolo, A. Del Zotto, F. Tarantelli and D. Zuccaccia, ACS Catal., 2016, 6, 7363; b) M. Gatto, A. Del Zotto, J. Segato and D. Zuccaccia, Organometallics, 2018, 37, 4685.

22 a) J. Catalán, M. Sánchez-Cabezudo, J. L. G. De Paz, J. Elguero, R. W. Taft and F. Anvia, J. Comput. Chem., 1989, 10, 426; b) F. Tomas, J. L. M. Abboud, J. Laynez, R. Notario, L. Santos, S. O. Nilsson, J. Catalan, R. M. Claramunt and J. Elguero, J. Am. Chem. Soc., 1989, 111, 7348; c) A. Escande, J. L. Galigne and J. Lapasset, Acta Crystallogr., Sect. B: Struct. Crystallogr. Cryst. Chem., 1974, 30, 1490; d) F. Tomas, J. Catalán, P. Perez and J. Elguero, J. Org. Chem., 1994, 59, 2799.

23 a) H. Ahlbrecht and G. Papke, Tetrahedron, 1974, 30, 2571; b) L. Kozerski, K. Kamienska-Trela, L. Kania and W. Von Philipsborn, Helv. Chim. Acta, 1983, 66, 2113; c) L. Kozerski, B. Kwiecien, R. Kawecki, Z. Urbanczyk-Lipkowska, W. Bocian, E. Bednarek, J. Sitkowski, J. Maurin, L. Pazderski and P. E. Hansen, New J. Chem., 2004, 28, 1562; d) L. I. Larina, V. G. Rozinov, M. Y. Dmitrichenko and L. A. Es'kova, Magn. Reson. Chem., 2009, 47, 149.

24 a) J. A. Akana, K. X. Bhattacharyya, P. Müller and J. P. Sadighi, J. Am. Chem. Soc., 2007, 129, 7736; b) T. J. Brown and R. A. Widenhoefer, J. Organomet. Chem., 2011, 696, 1216.

25 a) T. J. Brown, D. Weber, M. R. Gagné and R. A. Widenhoefer, J. Am. Chem. Soc., 2012, 134, 9134; b) D. Weber, M. A. Tarselli and M. R. Gagné, Angew. Chem. Int. Ed., 2009, 48, 5733; c) A. S. K. Hashmi, I. Braun, P. Nösel, J. Schädlich, M. Wieteck, M. Rudolph and F. Rominger, Angew. Chem. Int. Ed., 2012, 51, 4456; d) A. S. K. Hashmi, Acc. Chem. Res., $2014,47,864$.

26 a) A. S. K. Hashmi, Gold Bull., 2009, 42, 275; b) A. S. K. Hashmi, A. M. Schuster and F. Rominger, Angew. Chem. Int. Ed., 2009, 48, 8247; c) A. S. K. Hashmi, M. Wieteck, I. Braun, P. Nösel, L. Jongbloed, M. Rudolph and F. Rominger, Adv. Synth. Catal., 2012, 354, 555.

27 a) W. J. Tang and X. M. Zhang, Chem. Rev., 2003, 103, 3029; b) K. Gopalaiah and H. B. Kagan, Chem. Rev., 2011, 111, 4599; c) C. Margarita and P. G. Andersson, J. Am. Chem. Soc., 2017, 139, 1346; d) S. Kraft, K. Ryan and R. B. Kargbo, J. Am. Chem. Soc., 2017, 139, 11630. 
28 a) E. Haak, I. Bytschkov and S. Doye, Angew. Chem. Int. Ed., 1999, 38, 3389; b) I. Bytschkov and S. Doye, Eur. J. Org. Chem., 2001, 2001, 4411 d) M. A. Esteruelas, A. M. López, A. C. Mateo and E. Oñate, Organometallics, 2005, 24, 5084; e) M. L. Buil, M. A. Esteruelas, A. M. López and A. C. Mateo, Organometallics, 2006, 25, 4079; f) M. A. Esteruelas, A. M. López, A. C. Mateo and E. Oñate, Organometallics, 2006, 25, 1448; g) M. L. Buil, M. A. Esteruelas, A. M. López, A. C. Mateo and E. Oñate, Organometallics, 2007, 26, 554; h) A. Leyva-Pérez, J. R. Cabrero-Antonino, A. Cantín and A. Corma, J. Org. Chem., 2010, 75, 7769; i) T. Mahdi and D. W. Stephan, Angew. Chem. Int. Ed., 2013, 52, 12418

29 a) M.-A. Müller and A. Pfaltz, Angew. Chem. Int. Ed., 2014, 53, 8668; b) Q. Yan, D. Kong, M. Li, G. Hou and G. Zi, J. Am. Chem. Soc., 2015, 137, 10177; c) D. Kong, M. Li, R. Wang, G. Zi and G. Hou, Org. Lett., 2016, 18, 4916. 